\title{
Predgovor. Paralogije. Transformacije (post)modernističkoga diskursa u kulturi od 1920-ih do 2000-ih godina.
}

Članak je zadržan u integralnom obliku i odstupa od standardnog načina citiranja i navođenja izvora koji se primjenjuje u [sic]-u[1]

(...) Pojam „paralogija” uveo je Jean-François Lyotard kako bi označio novi tip legitimnosti ${ }^{[2]}$ koji se je oblikovao u suvremenoj kulturi - u postmodernoj situaciji krize globalnih metanarativa:

Postmoderna se znanost zanima za ono nerješivo, za granice točnosti kontrole, za kvant, za sukobe s nepotpunim informacijama, za „fracta”, za katastrofe, za pragmatičke paradokse, i time teoriju vlastite evolucije čini isprekidanom, katastrofičnom, neispravljivom, paradoksalnom. Ona mijenja smisao riječi znanje, i kazuje kako se ova promjena mogla dogoditi. Ona ne stvara poznato već nepoznato. Ona predlaže model legitimnosti koji nije povezan s najboljom performativnošću već s razlikom shvaćenom kao paralogija (Lyotard 2005: 88-89).

Pojašnjavajući tu kategoriju, Lyotard ističe da „paralogija” označava „moć koja destabilizira mogućnosti objašnjenja i koja se ispoljava proglašavajući nove oblike razumijevanja ili, ako hoćete, predlažući nova pravila znanstvene jezične igre koja određuju novo polje istraživanja" (ibid.: 91). Prema mišljenju toga znanstvenika, upravo je paralogija najdjelotvorniji i najmanje represivan način suprotstavljanja tradicionalnim oblicima ovjere znanja: paralogija ne skriva kontradikcije i protuslovlja iskaza, nego ih, suprotno, uzdiže u prvi plan kao kanale komunikacije s drugim, konkurentnim ili paralelnim iskazima, samim se time uključujući u proces jezičnih igara koji rađa novo znanje. Zbog toga smatram da je taj pojam važan i za razumijevanje transformacija ruskoga modernizma i postmodernizma i kao sredstvo opisa tih transformacija. Odatle i naslov knjige. 
Sada vidim da ova knjiga nije ni teorijska ni književno-povijesna. Iz perspektive teorije, ona previše pozornosti pridaje odabranim tekstovima. Iz perspektive povijesti, ona je previše općenita: između analiziranih su djela ostale velike praznine. Fenomeni koje sam odabrao za analizu sukladni su s teorijskom logikom (paralogijom) koja se u knjizi razvija. Ali oni teško da mogu ilustrirati teoriju prije bi se moglo reći da me potiču da je cijelo vrijeme nanovo osmišljavam. Zapravo, ono što se može označiti riječju „teoretiziranje” u mojem slučaju nije nesavitljiva okosnica koja u potpunosti prožima tekst knjige. Prije bi se moglo reći da teorijske hipoteze nastaju kao zaključci analize konkretnih tekstova i više nalikuju malenim povezima s prilijepljenim vijcima koje junak Stalkera Andreja Tarkovskoga baca pred sebe tijekom kretanja (također nelinijskog, ako se tko sjeća) po Zoni. Moguće da su zbog toga u knjizi tri uvodna teorijska poglavlja; po jedno za svaki odjeljak.

Riječima J.-F. Lyotarda, postmoderna „ulazi u modernu ${ }^{£ 3]}$. Međutim, ta filozofu samorazumljiva formula izaziva mnogo pitanja: kako se modernizam razlikuje od moderne, a postmodernizam od postmoderne? Znači li izgovoreno da „postmodernizam, naravno, ulazi u modernizam”? Koliko je to zapravo univerzalno i čime se dokazuje?

Ne očekujem da ću u cijelosti odgovoriti na do te mjere globalno pitanje: u Paralogijama govori se o tome da ruski postmodernizam ne samo da nije suprotstavljen ruskome modernizmu iz 1910-ih 1930-ih godina nego je - za razliku od zapadnoeuropskog ili sjevernoameričkog - jedna od važnih faza u povijesnome razvoju modernizma. Razvoju koji do danas nije završen.

Kao što, po svemu sudeći, ni kultura moderniteta (engl. modernity) nije završila, ona po okončanju Hladnoga rata nije „zasjala nad svijetom” (čemu se je nadao Francis Fukuyama - i ne samo on), nego je, posve suprotno, otkrila nepredvidiva proturječja, pa čak i sposobnost transformacije u „novo srednjovjekovlje” s vjerskim ratovima i općenitim rastom uloge religijskoga faktora u kulturi. Ipak, o pitanju kraja moderniteta mogli su se čuti i drukčiji glasovi. Posebice glas Jürgena Habermasa, koji je modernu nazvao nedovršenim projektom ${ }^{[4]}$ Međutim, Habermasu je misao o nedovršenosti „projekta” moderniteta poslužila za oštru kritiku postmodernizma i njegove filozofije (sličnu poziciju u suvremenoj Rusiji imaju B. Dubin i L. Gudkov, o čemu M. Lipoveckij detaljnije piše u 12. poglavlju knjige, op. prev.). A ruska kultura, po mome sudu, ilustrira ograničenost, pa i fiktivnost dihotomije moderna/postmoderna, omogućujući, ponavljam još jednom, da se 
postmodernizam promatra kao važan (premda, razumije se, ni blizu jedini) put razvoja moderne kulture i modernističke svijesti.

I ako se u povijesnom smislu modernizam oblikuje krajem 19. i početkom 20. stoljeća kao polilog međusobno suprotstavljenih diskurza, koji su istovremeno kritizirali kulturu moderniteta i predlagali svoje scenarije njezine obnove, tada se postmodernizam javlja na prijelomu 1960-ih u 1970e godine (i na Zapadu i u Rusiji) kao kritika modernističkih verzija kulture moderniteta, što se uostalom i posve točno upisuje u logiku modernističke svijesti, koja je nepokolebljivo i istrajno izlagala sumnji vlastite aksiome te potkopavala vlastite temelje.

U ruskoj kulturi te prilično apstraktne postavke posebice dobivaju na oštrini zbog sljedećeg: ako je na Zapadu postmodernizam niknuo kao reakcija na novu razinu razvoja kulture moderniteta (koju osobito romantični teoretičari nazivaju „postmodernošću”), tada se u Rusiji ili točnije, u Sovjetskome Savezu, gdje se pojavljuju prvi ruski postmodernistički tekstovi, ništa slično nije dogodilo. I doista, društveno-kulturna situacija tijekom koje je nastao ruski postmodernizam na prvi pogled nema ništa zajedničko ni s „kasnim kapitalizmom” (F. Jameson) ni s „civilizacijom masovnih medija” (J. Baudrillard), a posebice s „krajem povijesti” (F. Fukuyama). Zvuči paradoksalno, ali činjenica je da je ruski postmodernizam nastao u totalitarnoj kulturi ili - u manjoj mjeri - u bliskom, „komunalnom” susjedstvu s njom, razvijajući se paralelno i nalazeći se s njom u neposrednom i (češće) posrednom dijalogu.

Kako bi izbjegli taj, s ortodoksno-determinističkog gledišta neizbježan paradoks, neki suvremeni istraživači ruski postmodernizam pokušavaju predstaviti kao fenomen koji je prispodobiv isključivo postkomunističkom razdoblju. Tomu, dakako, nije tako. Razdoblje postkomunizma jedna je od kasnih faza umjetničkoga procesa koji je započeo u ruskoj neslužbenoj umjetnosti već u drugoj polovici 60 -ih i na početku 70 -ih godina 20. stoljeća. Pritom taj proces, suprotno uvriježenim pretpostavkama, nije bio zatvoren u granice undergrounda, nego je u znatnoj mjeri zahvatio i stvaralaštvo pisaca koji su bili priznati u službenoj sovjetskoj kulturi. R. Eshelman u svojoj monografiji Rani sovjetski postmodernizam (1997., Early Soviet Postmodernism, Frankfurt a. M; Berlin, Bern; New York; Paris, Wien: Peter Lang Publ.) uvjerljivo dokazuje da je u realističnoj prozi nastaloj u 70-im godinama prošloga stoljeća kriza sovjetskoga mentaliteta zaslužna za karakteristike usporedive s najvažnijim elementima postmodernističke „episteme”. Tako u temelju 
umjetničke filozofije zrelog Trifonova istraživač pronalazi rizomske (po Deleuzeu) - to jest nehijerarhične - veze svega sa svime: velikoga s malenim, osobnoga s povijesnim. Kod Vasilija Šukšina ponašanje je njegovih „čudaka” obilježeno „epistemološkom sumnjom” (D. Fokkema), nesposobnošću da razlikuju slobodu od podčinjenosti, sreću od tuge, vlastito gledište od nametnutog ili tuđeg itd.

Slijedom toga, više ili manje „autohtone” izvore ruskoga postmodernizma treba tražiti u logici sovjetske kulture moderniteta - ili one društveno-kulturne formacije koja se je oblikovala u SSSR-u „na mjestu” moderniteta kao posebnoga tipa kulture.

O pitanju odnosa između sovjetskoga modela prema tradicionalno shvaćenoj europskoj moderni intenzivno se raspravlja. R. Tuckef ${ }^{[5]}$ reagira protiv interpretacije staljinizma kao projekta modernizacije, inzistirajući na tome da su kultura i društvo toga razdoblja iskaz radikalnog neprihvaćanja moderne i povratka sovjetskoga društva u domoderne (dopetrovske) društvenokulturne modele. S. Coher ${ }^{[6]}$ govori o „dvjema sovjetskim Rusijama” - jednoj djelomice moderniziranoj (u velikim gradovima), industrijaliziranoj i tehnologiziranoj, i drugoj (seoskoj i seljačkoj), koja je radikalno arhaizirana. Moshe Lewin smatra da se sovjetski projekt modernizacije sukobio s tradicionalnom seljačkom kulturom većine stanovništva te je, boreći se s njom, na paradoksalan način apsorbirao upravo arhaične karakteristike seljačke svijesti: kolektivizacija i industrijalizacija doveli su do slijevanja seljaka u gradove, koji su bili ključna žarišta modernizacije. [7]

S druge strane, u nizu istraživanja s kraja 80 -ih i početka 90-ih godina 20. stoljeća sovjetsko se iskustvo nerijetko promatra kao „alternativni modernitet”, koji se temelji na pretpostavci da su i sovjetski model i liberalno-demokratske verzije moderne koje su se oslanjale prije svega na razvoj kapitalizma bili potaknuti „etosom društvenoga intervencionizma i masovne politike ${ }^{[8]}$. Tako Sheila Fitzpatrick pokazuje da su društveni temelj staljinizma u sovjetsko vrijeme postali oblikovani profesionalci: sovjetska „srednja klasa” inženjera, menadžera, vojnih zapovjednika, koji su u kulturnom smislu bili konzervativni, ali su bili tehnički pismeni i u političkom smislu odani režimu. ${ }^{[9]}$ Steven Kotkin pokazuje da se u 30-im godinama u Sovjetskome Savezu stvarao tako važan element kulture moderniteta 20. stoljeća kao što je to bio sustav državom osiguranih društvenih 
jamstava, tj. ono što se u drugom obliku na Zapadu naziva welfare state ${ }^{10]}$. Zygmund Bauman općenito povezuje raspad komunizma s krizom modernih strategija društvenoga „vrtlarstva” (tj. uvođenja racionalnog - ili onog koji se predstavlja kao racionalni - menadžmenta u odnosu na sve slojeve društvenoga i kulturnoga života) koji je došao u logičku slijepu ulicu[11]

Do obrata u proučavanju sovjetske civilizacije dolazi tijekom druge polovice 1990-ih godina u mnogome pod utjecajem metodoloških ideja M. Foucaulta. U središtu zanimanja nisu više politička borba, ideološke, ekonomske i državničke transformacije, nego prakse svakodnevice, infrastrukture društvenih veza i odnosa - poput vrijednosti, jezika i sociolekata, identiteta, vjerovanja, mitologije itd., koji su prožimali i kolektivni i individualni život sovjetskoga stanovništva. Središnja je kategorija u tom znanstvenom diskursu kategorija subjektivnosti, shvaćena kao proces međudjelovanja između pojedinca i države koji oblikuje društveni subjekt. ${ }^{[12]}$ Tako primjerice Kotkin u knjizi Magnetska planina: staljinizam kao civilizacija (Magnitnaja gora: Stalinizm kak civilizacija, 1995.) detaljno proučava društvenu infrastrukturu Magnitogorska u 30-im godinama prošloga stoljeća kao jedno od središta industrijalizacije. Kotkin prikazuje složeni proces pregovaranja i društvenog oponiranja, koji su uslijedili nakon industrijalne modernizacije i oblikovanja sovjetske verzije welfare state. Takva se analiza, dakako, ne uklapa u predodžbe o totalitarnom kao društvu koje je centralistički rukovođeno i u potpunosti kontrolirano „s vrha” i ona propituje primjenjivost koncepcije totalitarizma (u onom obliku u kojem ju je oblikovala Hanna Arendt) u kontekstu staljinizma kao civilizacije. S jedne je strane taj proces oponiranja, pregovaranja i korekcije projekata modernizacije karakterističan za „normalnu” kulturu moderniteta, čak i kada se ona razvijala u specifično sovjetskim oblicima, odnosno bez otvorene diskusije u tisku, bez višestranačja, bez slobode širenja informacija itd. S druge strane, Kotkin pronalazi dubinska protuslovlja sovjetskoga društva u sukobu između procesa modernizacije i teokratske uloge partije: „Obje su sastavnice partijske države bile funkcionalne, no njihove su se funkcije razlikovale: u vrijeme u kojem se je uloga države određivala u terminima kompetentne tehničke i ekonomske administracije, uloga se partije određivala u terminima ideološkog i političkog upravljanja. Takvo udvajanje političkoga sustava, u kojemu je uloga partije bila analogična ulozi crkve, podsjećalo je na teokraciju posebne vrste. (...) Oblikovanje teokratskoga sustava, koji je postupno dobio 
odgovarajuću religioznu auru, imalo je duboke posljedice, počevši od sakralizacije svih oblika djelovanja, velikih i malih, i završavajući u samouništenju (engl. self-immolation) same partije. ${ }^{\circledR 13]}$ Činjenica da su isti ljudi pripadali i partijskom i administrativnom rukovodstvu taj sukob nije rješavala, nego ga je samo produbljivala. Kotkin smatra da je to unutarnje protuslovlje između funkcija teokratskoga sustava - modernizirajuće i pseudoreligijske - jedan od osnovnih elemenata koji je doveo do terora tijekom 1930-ih, koji on promatra kao samouništenje sovjetskih elita. To samouništenje istraživač uspoređuje s inkvizicijom; njegovi su aspekti, osim spomenutog protuslovlja, društvena mržnja većine stanovništva prema „novoj klasi” sovjetske elite, koja je uživala niz privilegija, kao i mitologija neprijatelja, unutarnjeg i vanjskog (koju je stvorila vlast i koju je masovna svijest sa zahvalnošću prihvatila i rasprostranjivala). On je zaživio ne samo kao „žrtveno janje” na koje se je mogla svaliti krivnja za sve promašaje i neuspjehe modernizacije, nego i kao temelj sovjetskoga identiteta, koji se je oblikovao kao „antikapitalistički” (Lev Gudkov sovjetski identitet ne naziva slučajno „negativnim ${ }^{\lceil 14]}$ ). Važnu ulogu, smatra Kotkin, igraju i na toj podlozi oblikovani masovna paranoja i ksenofobija, koji hrane denuncijatsku „aktivnost masa”. Kotkinova koncepcija bliska je stavovima drugih suvremenih istraživača (A. Višnevskij, E. Dobrenko, B. Dubin i L. Gudkov, M. Kivinen, N. Kozlovaja, S. Fitzpatrick, I. Halfin, J. Hellbeck, D. Hoffman i drugi), koji u sovjetskom društveno-kulturnom modelu ne vide jedinstvenu, nego u mnogim smislovima krajnju varijantu „konzervativne” ili „regrutne” modernizacije. Po mome mišljenju, varijantu modernizacije koja se razvijala tijekom toga procesa točnije bi bilo nazvati arhaizirajućom, budući da se u toj paradigmi ciljevi vođenog progresivnog razvoja, učinkovitih i bezličnih državničkih instituta, racionalizacije i reguliranja društvenoga uređenja postižu aktualizacijom zastarjelih, tradicionalističkih i pseudoreligijskih metoda kolektivističke društvene integracije i identiteta. Poopćavajući logiku tog drukčijeg tumačenja staljinizma, E. Dobrenko navodi:

Glavni je ekonomski i politički događaj sovjetske epohe, sadržaj i zadaća staljinizma bila modernizacija države i prijelaz prema „discipliniranom društvu” (...) Međutim, rusko društvo, temeljeno na preddisciplinskoj tradiciji, nije bilo spremno - ni politički ni institucionalno ni kulturno za „disciplinirano društvo”. To je odredilo specifičnost staljinizma kao pothvata za stvaranje industrijskoga društva u preddisciplinskim oblicima (...) Boljševizam, ta ruska varijanta marksizma, 
nesumnjivo je bio opčinjen zapadnjačkom industrijaliziranom civilizacijom (...), što je bilo nerazdvojivo od vlastite ruske „egalitarističke, pseudokolektivistične, antitržišne, antiburžujske, antizapadnjačke, jednom riječju, 'socijalističke' utopije ${ }^{[15]}$. Ta podvojenost prožima cijelu sovjetsku ideologiju, u kojoj se patos industrijalizacije oslanja na „tradicionalne vrijednosti”, ideologija „proleterskog internacionalizma” može u potpunosti ići ruku pod ruku s borbom protiv „odrođenoga kozmopolitizma”, a „poezija osvajanja prirode” saživljuje se s posvema konzervativnom „poezijom male domovine" itd. ${ }^{[16]}$

Put arhaičnoga moderniteta obično je povezan s modernizacijom koja ima karakter kašnjenja ili sustizanja. On postoji i u drugim totalitarnim kulturama - prije svega u talijanskom fašizmu, njemačkom nacizmu, kineskom maoizmu, kubanskome socijalizmu - a kao tendencija postoji i u modernijim kulturama. Taj je put oživljen prije svega zbog straha od moderniteta i njegovih posljedica: raskida s tradicijama, porasta uloge birokracije, fragmentacije i atomizacije kolektivnih tijela (konfesionalnih, regionalnih, etničkih, cehovskih itd.). U cijelosti je cilj arhaičnoga moderniteta u tome da suzbije eksponencijalni rast složenosti kulture i društvenoga života, koji kod „masovnoga čovjeka" rađaju spoznaju o besmislenosti i izgubljenosti. Temeljen na traumi moderniteta, sovjetski je socijalizam, po točnom određenju M. Ryklina, „bio takva zamišljena totalna kompenzacija za traumu: tu je ulogu, po svoj prilici, jedinu odigrao do kraja ${ }^{\text {[17] }}$.

Zajedno s time arhaični je modernitet neprestance rađao nove i nove traume - ne samo zato što se nasilje pokazalo kao najefikasniji način rješavanja neprestano novih protuslovlja nego i zato što je sovjetska teokracija, kao i svaki religijski sustav, trebala neprestano nove žrtve, čime je ne hoteći stvarala mehanizme koje su opisali G. Bataille u Prokletom dijelu i R. Girard u raspravi Nasilje i sveto!18] Na tome se tlu oblikovala „tanatološka perspektiva staljinističke kulture ${ }^{\lceil 19]}$, koju su isticali različiti istraživači. Tako M. Ryklin piše o „dominaciji u postrevolucionarnoj kulturi iskustva nasilne smrti”, naglašavajući: „Nasilna se je smrt nesvjesno počela doživljavati kao norma, ona je postala model za svaku drugu smrt, dok je na Zapadu, bez obzira na ratove i prirodne kataklizme, dominirala paradigma prirodne biološke smrti. ${ }^{\{20]}$ Igal Halfin u svojoj knjizi o autobiografijama komunista (i o kategorijama dobra i zla u sovjetskoj kulturi) opisuje „komunističku eshatologiju” po kojoj će se „besklasno društvo ostvariti kada se proletarijat očisti od zlih duša”. Ta je ideja, prema Halfinovu mišljenju, „legla u temelje ideološke matrice u kojoj je sveprisutno nasilje imalo moralni 
smisao ${ }^{\$ 21]}$. Knjiga završava sljedećim zaključkom: komunisti su „vidjeli (...) jedinstveni način za ostvarivanje svoga života, no budući da se je taj smisao shvaćao transindividualno i transpovijesno (tj. transcendentalno, u skladu s religijskom dominantom sovjetske kulture, op. M. L.), život se je izjednačavao sa smrću. U određenom je smislu pristupanje partiji bilo samoubilački čin: smrt autonomnoga, samodostatnoga individuuma ${ }^{\{22]}$. E. Dobrenko u razvoju sovjetske kulture od 1920ih do 1950-ih godina otkriva sljedeću shemu: „u raspravama o 'osvajanju prirode' i diskurzu metaforičkoga nasilja koje se je u njima stvaralo došlo je do 'otkrića postupka'; potom u diskurzu pedagoškoga nasilja, koji se je temeljio na 'preodgoju', dolazi do 'obnaživanja postupka'; na koncu, u praksama skrivenoga nasilja, povezanih s rutinizacijom terora, u kojem se je učvršćivao 'magični diskurz' transformacije socrealističkog junaka, pred nama je 'skrivanje postupka'. ${ }^{[23]}$ Slijedeći tu logiku, valja priznati da je upravo nasilje postalo glavni označitelj sovjetskog sakralnog.

Naravno da je sovjetski arhaični modernitet neko vrijeme čekao ne samo na oksimoronsko savladavanje traume moderniteta uz pomoć umnožavanja traume i sakraliziranja nasilja. Istraživanja sovjetske subjektivnosti su time cjenjenija što više ogoljuju diskurzivne oksimorone na svim razinama sovjetske kulture i društva: državničkom, političkom, ideološkom, ekonomskom, psihološkom i egzistencijalnom. Radi najdosljednijeg uklanjanja tih protuslovlja iz polja kulture zapravo i nastaje socrealizam - „mehanizam realizacije socijalizma na račun istovremene derealizacije života ${ }^{\{24]}$. Međutim, istovremeno se oblikovao i spektar drukčijih diskurza, čiji su autori pažljivo promatrali oksimorone arhaičnoga moderniteta te su u njima tražili tumačenje ne samo sovjetske povijesti i civilizacije nego su kroz njih tumačili metanarative povijesti, kulture i ličnosti, na kojima se temeljila kultura moderniteta.

Jedan je od takvih diskursa bio groteskni realizam 1920-ih i početka 1930-ih godina (rani M. Bulgakov, N. Ėrdman, I. Il'f i E. Petrov, M. Zoščenko). Drugi je bio modernizam I. Babelja, E. Zamjatina, B. Pil'njaka, L. Dobyčina, O. Mandel'štama, A. Ahmatove, M. Cvetaeve, M. Kuzmina, A. Platonova, B. Pasternaka, K. Vaginova, S. Kržižanovskoga, kasnoga Bulgakova, V. Nabokova, B. Poplavskog, G. Gazdanova i drugih. Treći je diskurs bila avangarda, također vrlo široka po svom spektru: od LEF-a do OBÈRIU. Do državničkog socrealističkog monopola ti su diskursi s promjenjivim uspjehom još postojali u polju „dopuštene kulture”, međutim od početka 30-ih godina oni su posvema potisnuti ili u neslužbenu ili u emigrantsku kulturu. Do njihova djelomičnoga 
povratka u sovjetsku kulturu dolazi tek tijekom 60-ih godina prošloga stoljeća istodobno s raspadom sovjetskoga arhaičnog moderniteta. Točnije, razvoj modernističkih diskursa nastavlja se većinom u nezavisnoj književnosti, ali klasici modernizma iz 20-ih i 30-ih godina postupno se vraćaju čitatelju (razumije se, u strogo doziranom i pročišćenom obliku). Istodobno dolazi do adaptacije određenih karakteristika modernističke estetike u objavljenoj književnosti (A. Voznesenskij, rani V. Sosnora, V. Aksenov, filozofske fantazmagorije braće Strugackih, roman „struje svijesti” Mykolasa Sluckisa u 60-im, a u 70-im i 80-im godinama - estonska apsurdistička proza, mitološki roman Otara Čiladzea, Čingiza Ajtmatova, Anatolija Kima, Vladimira Orlova, egzistencijalni roman Jurija Trifonova itd.).

Ako je u tradicionalnim kulturama „žrtveno janje” rješavalo nastale krize, pri čemu je na sebe preuzimalo odgovornost za unutarnja protuslovlja društva (o čemu je pisao R. Girard), u sovjetskoj je kulturi sama „produkcija neprijatelja” postala najvažniji preduvjet njezina uspješnog razvoja ${ }^{[25]}$ Upravo je zbog toga arhaični modernitet mogao funkcionirati samo na podlozi društvenih katastrofa i kriza (od 1920-ih do 1950-ih godina), i to takvih koje su ili umjetno izazvane uz pomoć unutrašnjeg terora i retorike „opkoljene tvrđave” ili su prirodno zaoštrene tijekom rata. Premda nedosljedno, odjuga 1960-ih oslabjela je situaciju permanentne krize i samim time potkopala mehanizam žrtvovanja, oslobodila je kulturnu mitologiju „izvora na kojima se prehranjivala” te pokrenula proces postupnog, laganog, no nepokolebljivog sloma cjelokupnog kulturnog modela koji se protegnuo na gotovo četiri desetljeća.

Kako god bilo, raspad sovjetskog arhaičnog moderniteta, koji je započeo tijekom 1960-ih godina i nastavio se s promjenjivim uspjehom do „perestrojke”, povezan je prije svega sa slomom metanarativa „sovjetskog sakralnog”. Ono je izgubilo na autoritetu usporedo sa slabljenjem državničkog terora. Osim toga, njegovi rituali i instituti sve manje odgovaraju na složenije potrebe društva i kulture, sve se više automatiziraju i desemantiziraju, istovremeno stvarajući nove diskurze - kako sakralne, tako i desakralizirajuće - koji su bili polemički raspoloženi prema sovjetskoj pseudoreligiji.

Hibridni karakter sovjetske kulture moderniteta oživljava suprotstavljene strategije njezine kritike: ili iz vizure izgubljenih i „oskvrnjenih” domodernih tradicija ili iz vizure manjkavosti i nerazvijenosti vlastitoga projekta moderne. Prvi (resakralizirajući) tip kritike utjelovljuje nacionalistički diskurs 
„posebnoga puta” Rusije, iracionalne „ruske duhovnosti”, pravoslavlja, „izvornih” (seljačkih i patrijarhalnih) tradicija. Kritika moderniteta u tom diskurzu (u rasponu od Solženicyna i „derevenščika” do autora u časopisima „Naš sovremennik”, „Molodaja gvardija” i „Veče”, različitih varijacija „nove desnice” i ruskoga fašizma ${ }^{26]}$ ) izražava se u interpretaciji sovjetskoga režima kao rezultata invazije sila koje su strane ruskoj kulturi, za što je poslužila predodžba o Zapadu i židovima kao agentima kolonizacije (modernizacije), kao i industrijsko-urbanistička civilizacija u cijelosti. Suvremena kritika sovjetske sakralnosti, koju reprezentira zapadnjački, liberalnodisidentski diskurs (u rasponu od A. Saharova i A. Amal'rika do Ju. Trifonova ili V. Aksenova), koji je pretrpio evoluciju od „povratka oskvrnutim revolucionarnim idealima” (jasno je da mnogi nisu vjerovali u tu iluziju - Arkadiju Belinkovu i Lidiji Čukovskoj to se nikako ne može spočitnuti), do kulta „općeljudskih vrijednosti”, među kojima je na prvo mjesto došla individualna sloboda, nadaje se kao suprotnost sovjetskom pseudoreligijskom kolektivizmu. ${ }^{[27]}$ Ti diskursi u kulturi od 1960-ih do 1980-ih, razumije se, nisu bili izolirani ni od službenoga diskursa sovjetske mitologije ni jedan od drugoga. Ilustrativna je, primjerice, „diskurzivna hibridnost” časopisa „Novyj mir” Tvardovskoga ili „prebacivanja” pisaca osjetljivih na smjene ideološke mode poput E. Evtušenka i A. Voznesenskoga, ili pak, kada govorimo o necenzuriranoj književnosti, složena i ambivalentna ideološka pozicija A. Sinjavskog, koja je u sebi uključivala i oduševljenost revolucionarnom romantikom iz 1920-ih godina i interes prema folkloru kao glasu „duboke”, „nepoznate” Rusije, kao i „zapadnjačka” liberalna uvjerenja te privrženost avangardnoj književnosti[28] Važno je naglasiti da se „domoderni” diskurzi, odnjegovani u krugu „derevenščika” i u drugim strujanjima neslužbenih nacionalista, krajem 1970-ih i početkom 1980-ih godina skriveno prilagođavaju u sovjetskim službenim glasilima: značajan dio sovjetske elite u to vrijeme svodi „moderne” elemente sovjetske retorike na slaborazumljive idiome ${ }^{[29]}$

Kakvu ulogu igra postmodernistički diskurz u toj, razumije se, posvema pojednostavljenoj shemi? Pojavljujući se kao proizvod raspadanja sovjetskoga sakraliziranoga moderniteta, on se je suprotstavljao i „modernim” i „predmodernim” modelima kritike sovjetskoga mita i svijeta, udaljavajući se od njih kao od podjednako ideoloških i utopijskih, odnosno prepoznavajući u njima neke od sovjetskih metanarativa, a češće jednostavno varijacije sovjetskih metanarativa (redigirane ili „očišćene”). Kao što je pisao primjerice D. A. Prigov: 
(...) naša je svijest bila kulturnokritička: kritizirali smo i utopije i državničke institucije, koje su ih producirale, i totalitet svakog jezika, koji je prije svega bio povezan s državničkim jezikom. Kod nas je svaki utopijski jezik izazivao jaku alergiju. Jedan je od nositelja utopijske svijesti bila disidentska umjetnost, koja je također bila predmet naših reakcija i kritike... Primjerice, Puškin i Majakovskij za nas su bili uobičajeni predstavnici sovjetske vlasti. I ne samo to: iz naše su vizure duhovni orijentiri ranije generacije, poput Ahmatove i Pasternaka, nakon objavljivanja popadali u diskurs vlasti. ${ }^{[30]}$

Slične, premda ne uvijek artikulirane reakcije oblikuju cinički - po točnom određenju A. Yurchaka ${ }^{31]}$ - karakter kulture „kasnoga socijalizma”, tijekom kojega se je punom parom odvijao „lyotardovski” proces „truljenja” sakraliziranih ideologija, metanarativa i utopija. Raspadajuća sovjetska utopija kao da je zarazila svojim gljivicama one protuideologije i protukulture koje su se oblikovale u njezinoj sjeni. A kasnosovjetski cinizam, kako piše Yurchak, bio je srodan postmodernizmu po svojoj unutrašnjoj logici - odatle takvi fenomeni poput „masovne” postmodernizacije tijekom 70-ih i 80-ih godina, kao što su „steb ${ }^{\lceil 32]}$ i crni humor. Upravo je cinička svijest „posljednje sovjetske generacije" rodila i trebala rusku verziju postmodernizma.

Druga je konstanta postmodernog diskurza u kasnosovjetskoj kulturi ne samo orijentacija njegovih nositelja na umjetnost ruskog i europskog modernizma i avangarde nego i općenita težnja da se stvara kao da nikakvog socrealizma ni nije bilo. S. Savickij u zaključku svoje knjige o leningradskoj neslužbenoj umjetnosti utvrđuje: „Leningradski neoavangardisti nisu željeli sahraniti modernizam, budući da za njih on još ni približno nije bio iscrpljen. (...) Neslužbena kultura htjela je stvoriti iskustvo modernizma i avangarde s početka 20. stoljeća. 'Helenukty ${ }^{[33]}$ su koristili tehniku dadaističkoga kolaža. Aleksej Hvostenko bio je zanesen zaumnom poezijom Velimira Hlebnikova i Alekseja Kručenyha, Konstantin Kuz'minskij pokušavao je ostvariti nerealizirane konstruktivističke projekte... S povijesnoga je gledišta moguće govoriti ne toliko o eklektici koliko o okretanju književnoj tradiciji iz razdoblja od 1910-ih do 1920-ih godina, pri čemu se je ignoriralo razdoblje od 1930. do $1940 .{ }^{{ }^{334]}}$ Do sličnih zaključaka dolazi i V. Kulakov nakon što je protumačio uglavnom moskovski pjesnički underground od 1960-ih do 1980-ih godina ${ }^{[35]}$ Rečeno, međutim, ne dokida ni polemički odnos prema avangardi/modernizmu (što je posebice vidljivo u moskovskom konceptualizmu) ni to da se je orijentacija prema avangardi kod neslužbenih umjetnika i pisaca 
tijekom svoga razvoja prepravljala u nešto novo - neomodernizam (R. Mandel'štam, V. Krivulin, A. Mironov, E. Švarc, L. Aronzon, pjesnici grupe „Moskovskoe vremja”), neoavangardu (pjesnici„lianozovcy ${ }^{£ 36]}$, „,helenukty” i blizak toj grupi A. Hvostenko, „smogisty ${ }^{\lceil 37]}$, V. Kazakov itd.). Međutim, i u jednom i u drugom slučaju u tim su se pravcima osjećale načelno nove postmodernističke - tendencije koje, dakako, nisu bile suprotstavljene spomenutim estetikama, nego su se prije oblikovale kao rezultat mutacija avangardnih i modernističkih principa kojima ni sami autori često nisu upravljali.

„Zadaća je dekonstrukcije u identifikaciji i razrušenju binarne opozicije. (...) Taj se proces sastoji od dviju nužnih operacija. Kao prvo, binarna opozicija mora biti preokrenuta (...) Drugi, ne manje važan uvjet dekonstrukcije neizbježno je izguravanje cijelog sustava binarnog mišljenja. Članovi opozicije moraju biti osmišljeni izvan binarne logike. ${ }^{\lceil 38]}$ Riskirat ću ako zaključim da tragove takvog preosmišljavanja možemo naći u svakom postmodernističkom tekstu te da se upravo težnja prema slamanju binarnih opozicija u ruskoj kulturi nalazi kao odgovor na grubu, sakraliziranu binarnost koja je organizirala i kroz službene i kroz neslužbene diskurse kasnosovjetske kulture (govoreći to, dakako da se oslanjam na poznatu koncepciju Ju. M. Lotmana i B. A. Uspenskog, o čemu podrobnije pišem u 1. poglavlju knjige). Pritom se dekonstrukcija (premda se sama riječ, koju je filozofskim pojmom učinio Jacques Derrida u knjizi O gramatologiji, u Rusiji nije upotrebljavala do 1990-ih godina) poistovjećuje sa strategijom oslobođenja od pritiska različitih „transcendentalnih označitelja", koji su prispodobivi jednog ili drugoj sakraliziranoj ideologiji. Istovremeno je taj proces praćen mučnim refleksom pitanja može li kultura uopće postojati izvan „transcendentalnih označitelja", izvan potrage za apsolutima (ma koliko god oni bili individualizirani i neuhvatljivi). Taj se refleks, dakako, zaoštrava izrazitom književnocentričnošću ruske i sovjetske kulture i ona dovodi do karakterističnih transformacija samoga mehanizma dekonstrukcije, koji određuje po mom sudu ne samo povijesnu nego i strukturnu specifičnost ruskoga postmodernizma. Te se transformacije tumače u prvom poglavlju knjige; njima su posvećena i prva poglavlja svakog sljedećeg odlomka.

Nemogućnost da se velika kultura moderniteta oslobodi od odgovornosti za povijesne katastrofe 20. stoljeća, prije svega za Drugi svjetski rat i holokaust; svijest o nasilju koje leži u temeljima 
logocentrične kulturne svijesti, strukturirane na binarnim opozicijama; razočaranje u metanarative moderniteta, koji su kompromitirani jer se u njihovo ime opravdavao i često njima čak i nadahnjivao teror većine nad manjinom; potrage za metodama neutralizacije i transformacije diskurzivnog nasilja - to su najvažnije pretpostavke oblikovanja postmodernističkih strategija u poslijeratnim europskim i američkim kulturama. „Ako je nasilje inicijalan diskurs, on se može podvrgavati samo nasilju, negirati se. Kako bi se učvrstio, jedino što on može jest voditi rat s ratom, oblikujući diskurs bez mogućnosti povratka samomu sebi kao diskursu negativnosti... Taj je drugi rat... najmanje nasilje, jedina mogućnost da se suzbije najgore nasilje, a to je nasilje primitivne i predlogičke šutnje, neizrecive noći... ${ }^{{ }^{39]}}$ - u tom se Derridaovom komentaru (1967.) filozofskih radova Emmanuela Levinasa, koji je preživio nacističke koncentracijske logore, nalazi jedan od najvažnijih motiva postmodenrističke dekonstrukcije logocentrizma.

Međutim, nije li sličnu misao 1943. olovkom napisao M. M. Bahtin?

Element nasilja u spoznaji i u umjetničkoj formi. Izravno proporcionalan nasilju element laži. Riječ plaši, rađa nadu, slavi ili kudi (isprepletenost slave i kletve neutralizira laž)... U čemu je umrtvljujuća snaga umjetničke slike: zaobići predmet sa strane budućnosti, prikazati ga u istrošenosti i time mu uskratiti otvorenu budućnost, prikazati ga u svim granicama, i unutarnjim i vanjskim, bez za njega svakog izlaska iz te ograničenosti - [ako] je on ovdje i do kraja, mrtav je i može ga se progutati, on se konfiscira iz nedorečenog života i postaje predmet moguće uporabe (...). Uskraćena mu je sloboda, čin spoznaje želi ga okružiti sa svih strana, izrezati ga iz nedorečenosti $i$, slijedom, iz slobode, iz vremenske i smisaone budućnosti, iz njegove neodlučnosti i njegove unutarnje istine. Isto čini i umjetnička slika, ona ne uskrsava i ovjekovječuje radi same sebe (nego za sebe) (...). To nasilje u slici organski je vezano uz strah i prijetnju[40]

Naravno, Derrida govori o logičkom mišljenju, fundamentalnom za racionalizam kulture moderniteta, a Bahtin o slikovnom, koje određuje paralogiju književnocentrične kulture. Ali zaključci do kojih dolaze iznenađujuće su slični. To nije slučajna podudarnost.

Kao što nisu slučajna i nepredvidiva podudaranja Autora u Egipatskoj marci i lakanovske koncepcije Realnoga, Harmsove apsurdističke metafizike i teorije alegorije V. Benjamina, Lolite i Baudrillardove „hiperrealnosti simulakruma”. Jer reakcija usmjerena prema spoznavanju veze između velike kulture i terora, radikalne modernizacije i povratka u divljaštvo, što leži u temeljima 
europske postmodernističke misli, rađa se u ruskoj kulturi puno ranije - na prijelazu 1920-ih u 1930-e godine.

Taj se je refleks morao dogoditi u Rusiji i zbog književnocentričnoga karaktera ruske kulture i zbog toga što je krvava narodna revolucija doista bila mesijanska mašta značajnoga dijela (premda ni približno ne cijele) ruske inteligencije, i zbog golemosti kulturnoga prevrata koji se je dogodio u 20im i 30-im godinama prošloga stoljeća. (Zanimljivo je da je zamašnjak toga refleksa oslabio tijekom kritike kulta ličnosti: sovjetski se je režim u to vrijeme prikazivao kao čisto utjelovljenje apsolutnoga zla, poginuli umjetnici i mislitelji za kulturu su postali novi sveti mučenici, zbog čega su razmišljanja o odgovornosti visoke kulture za povijesne katastrofe naprosto neumjesna. $)^{[41]}$ Estetika modernizma najprimjenjivija je kako bi s krajnjom oštrinom problematizirala vjeru u spasiteljsku moć kulture, trenscendentalnu ulogu umjetnika, harmoniju umjetnosti i njezin plemenit utjecaj na društvo. Upravo problematizacija postulata moderne, pojava disonansi i proturječja, koji su se krojili u utopijama univerzalne sreće i globalne harmonije, zapravo i određuju kulturnu ulogu modernizma ${ }^{[42]}$ Smjer te problematizacije u postrevolucionarnom ruskom modernizmu (u manjoj se mjeri to odnosi na politički angažiranu avangardu, koja je ionako razvijala utopijske modele) rađa diskurzivne strukture i estetske modele u kojima se oblikuju i „učvršćuju” nerazrješiva protuslovlja moderniteta - ona tragična pitanja oko kojih i u okviru kojih zapravo i dolazi do razvoja postmodernizma, kako zapadnog, tako i ruskog.

Čini se da nisam sam u takvom odnosu prema modernizmu 1920-ih-1930-ih godina. Ne bez razloga danas niz istraživača (S. Bojm, B. Grojs, A. Zorin, D. Kujundžić, S. Savickij, I. Sandomirskaja, A. Ėtkind i neki drugi) intenzivno iznova čita modernističke autore kroz prizmu teorije kulture koja se oblikovala u postmodernističkom kontekstu. Nije slučajno da su mnogi spomenuti autori dosta napravili i u analizi upravo ruskoga postmodernizma. Je li pritom riječ o aberaciji recepcije, „pokvarene” poststrukturalističkom teorijom? I to je moguće, no svejedno smatram da taj preokret paradigme u paradigmi čitanja ima i drugi, puno važniji uzrok. Sama mogućnost novoga (želim vjerovati heuristički produktivnog) čitanja klasičnih tekstova ruskih modernista kroz postmodernističku prizmu svjedoči o tome da je kulturna logika ruskoga postmodernizma pojava vezana uz preokrete dublje od „kasnog kapitalizma” ili sloma komunizma. 
Iz te su vizure za mene u povijesti ruskoga modernizma posebice važni Vaginov, Mandel'štam, Harms i Nabokov, premda se u stvaralaštvu tih autora, dakako, ni u kojem slučaju ne iscrpljuje spektar umjetničko-filozofskih reakcija o odnosu kulture i terora. Smatram da se u tom smislu ne mogu zaobići ni Tynjanov, ni Platonov, ni Zoščenko, ni Šalamov $!^{[43]}$ Moj se odabir (u knjizi Paralogije, op. prev.) temeljio na utjecaju koji su autori Egipatske marke, Poslova i dana Svistonova, Slučaja i Lolite izvršili na oblikovanje i evoluciju upravo postmodernističkoga diskurza. No ako su me ranije Vaginov, Mandel'štam, Harms i Nabokov zanimali prije svega kao preteče postmodernističke metaliterarnosti, danas njihova otkrića promatram kao ranu dijagnozu onih kulturno-filozofskih prijeloma, onih procjepa u samoj predodžbi o kulturi i njezinih egzistencijalnim mogućnostima (predodžba koja dolazi iz renesanse, razvija se tijekom prosvjetiteljstva, individualizira tijekom romantizma i „objektivizira” u tzv. realizmu) koji su se tek tijekom posljednje trećine 20. stoljeća beskonačno raširili, zapravo i oblikujući „semiosferu” postmodernizma.

Zapravo, „morfologiju” tih procjepa ja i pokušavam opisati u drugom i trećem dijelu knjige. Drugi dio započinje poglavljem u kojem se poopćuje modernističko iskustvo u okvirima teorijskoga modela postmodernističkoga diskurza, koji se temelji na strukturalnom međudjelovanju praznoga središta i iteracije. Na temelju tog modela predlažem tipologiju osnovnih strujanja u ruskom postmodernizmu od 1960-ih do početka 1990-ih godina - konceptualizma i neobaroka. (Smatram da je model koji se temelji na tim nazivima prilično specifičan za rusku kulturu, premda „odjekuje” i u drugim, prije svega postkomunističkim i postkolonijalnim književnostima. Supostojanje i međudjelovanje tih tendencija analizira se na primjerima važnih ruskih postmodernističkih tekstova poput romana poeme Moskva-Petuški Venedikta Erofeeva, poezije Leva Rubinštejna, romana Viktora Pelevina, Vladimira Sorokina, Tat'jane Tolstoj i Leonida Grišoviča.)

Potrebno je još jednom naglasiti da ne pišem povijest ruskog postmodernizma. Zanimaju me upravo paralogijska - to jest iracionalna i alogična - premještanja autoritetnih diskurza, mitova i hijerarhija, koji su izazvani „slomom središta”, krizom transcendentalnog označitelja kulture. Umjesto ekstenzivnog opisa raznolikosti povijesnoga razvoja u svoj njegovoj punini prednost dajem metodi „točkastoga bušenja”: čini mi se da pomna analiza odvojenih, premda posvema reprezentativnih tekstova, adekvatnije odgovara na postavljeni zadatak. Do preokreta dolazi u 
dubini (u tom kontekstu - i u dubini autorske svijesti) i pri „panoramnom” pogledu njihova se složena i raznolika struktura neizbježno pojednostavljuje i ublažava.

Tu metodu primjenjujem i u trećem dijelu knjige, posvećenom transformaciji ruskog postmodernističkog diskurza u 21. stoljeću. Odlučno sam protiv naširoko popularnog mišljenja o „kraju postmodernizma”, premda je nemoguće ne primijetiti promjene koje se danas događaju u postmodernističkome diskurzu. Te su promjene očigledno povezane s novom društveno-kulturnom situacijom, oblikovanjem novih, komercijalnih i masovnih mehanizama funkcioniranja kulture, kao i - u puno većoj mjeri - s općenitim stupanjem na scenu neokonzervativnih i neotradicionalističkih koncepcija. Međutim, neotradicionalistički preokret, ili točnije: redovit pokušaj sjedinjavanja arhaizacije društva i politike s modernizacijom ekonomije ne samo da ne ukida dramatična pitanja o vezi između kulture i nasilja, koja je razvijena u ruskom modernizmu još krajem 1920-ih godina, nego im daje i novu - no ovoga puta društvenu - oštrinu. Pokušavajući shvatiti u kojoj mjeri ruski postmodernistički diskurz odgovara na ta pitanja, u tom dijelu knjige postavljam još jednu hipotezu - o kasnom postmodernizmu. Ako je moguće suditi po „novom autobiografizmu”, detektivskim romanima B. Akunina, novim djelima Pelevina i Sorokina, filmovima A. Rogožkina i A. Balabanova, „novoj drami” i kazalištu braće Presnjakovyh ${ }^{44]}$, „kasni postmodernizam” od konceptualizma i neobaroka iz razdoblja od 1960-ih do 1990-ih razlikuje se prije svega po svojoj usmjerenosti na probleme identiteta (društvenoga, kulturnoga, rodnoga, etničkoga itd.). Upravo je zbog toga glavna poveznica svih skrivenih i javnih paralogija siže Drugoga. Za taj je siže važno i to kako se modelira Drugi; i to kako se problematizira opozicija „svoga” i „tuđega”; i to kako se uspijeva ili ne uspijeva prenijeti „drukčijost” druge svijesti, iskustva, identiteta; i, naposljetku, to kakvu ulogu igra nasilje doslovno ili simboličko - u odnosima s Drugima koje je autor izgradio ili izmislio.

Pokušaji da se na nove načine Drugi i „drugo” upiše u tkanje postmodernističkoga diskurza vidljivi su i u tome što se u „kasnom postmodernizmu” struktura paralogičnih (eksplozivnih) aporija isprepleće s traženjem više ili manje čvrstih hibridnih - premda i kao i ranije eksplozivnih, dubinski proturječnih - tvorbi u estetici, kulturi, čak i u društvu, pri čemu jedna od sastavnica hibrida neizostavno postaje Drugi i „drugo”. Eksplozivni hibridi koji nastaju u „kasnom postmodernizmu” također se „rimuju” s iskustvom ruskoga modernizma iz 1930-ih godina. Dovoljno je prisjetiti se nevjerojatnih hibrida vražjeg i božanskog (M. Bulgakov), utopije i apokalipse (A. Platonov), 
socrealizma i slavenskoga jurodstva (L. Leonov) kako bismo se uvjerili da kasni postmodernizam svjesno ili nesvjesno obnavlja iskustvo kasnoga modernizma.

Imao sam priliku čuti mišljenje o tome da pri interpretaciji postmodernizma kao jednog od modernističkih diskurza sam pojam „postmodernizam” dezorijentira, budući da pojave koje se njime opisuju nikako ne nastaju nakon modernizma, nego u povijesno izmjenjivoj modernističkoj paradigmi. S time sam se spreman složiti - odatle i zagrade oko prefiksa „post-” u podnaslovu knjige. Na kraju krajeva, Vladimir Novikov već je predlagao da se „postmodernizam” zamijeni riječju „pozdmodernizam” (odnosno pozdnyj modernizm, tj. kasni modernizam, op. prev.) zbog, prvo, intelektualne ekonomije i, drugo - jer se je kategorija modernizma povijesno oblikovala kao dovoljno gipka i pokretna (premda to ne znači da je bezgranična). Modernizam je uspješno u sebi inkorporirao i simbolizam, i akmeizam, i ekspresionizam, i nadrealizam, i apsurdizam, i mnoge druge „izme”. Zar se na tom bogatom drvetu ne može naći mjesta za jaku granu pod imenom „postmodernizam”? Zar je potrebno da se ona, ta grana, neizostavno pomiče na neku ograđenu „parcelu”? Što se tiče netočnosti termina, ionako je naša disciplina daleka od egzaktnih znanosti u tom smislu čak ni strukturalizam nije bitno promijenio situaciju. Ne bez razloga ni do danas granice između realizma i naturalizma, ili futurizma i ekspresionizma, ili nadrealizma, dadaizma, obèriuta i apsurdizma nisu posvema raščišćene. To nas, međutim, ne sprečava da baratamo tim pojmovima.

Izvor: Lipoveckij, Mark. Paralogii. Transformacii (post)modernistskogo diskursa v russkoj kul'ture 1920-2000-h godov. Novoe literaturnoe obozrenie, 2008, str. V-XXVIII.

Prevela: Danijela Lugarić Vukas 
[1] Nepotpuni prijevod Predgovora ranije je objavljen u „Treći program Hrvatskoga radija”, br. 85, 2013. Ovaj je prijevod nadopunjen ranije ispuštenim dijelovima i temeljito je redigiran. Cjelovita knjiga Marka Lipoveckog sastoji se od tri velike cjeline, naslovljene Metamorfoze postmodernizma; Konceptualizam i neobaroko te Kasni postmodernizam, u kojima se Lipoveckij bavi nizom primjera iz novije ruske književne kulture (od, između ostalih, stvaralaštva O. Mandel'štama, K. Vaginova, D. Harmsa i V. Nabokova, potom Ven. Erofeeva, L. Rubinštejna, T. Tolstoj, V. Pelevina i V. Sorokina do G. Bruskina i braće Presnjakovyh). Premda je ovaj književni povjesničar i teoretičar već 1997. godine objavio knjigu Ruski postmodernizam: nacrt povijesne poetike (Russkij postmodernizm: očerki istoričeskoj poètiki), u Predgovoru ističe da knjiga čiji dio prevodimo nije „prošireno i dopunjeno” izdanje starije knjige o postmodernizmu, nego je riječ o novim, „zrelijim” tezama o ruskom postmodernizmu. O kakvim je tezama riječ detaljno se i argumentirano objašnjava upravo u prevedenim dijelovima (op. prev.).

[2] Uz paralogiju, legitimitet (koja se vezuje uz diskurz moći, igru, kulturni imperijalizam, moć, postmodernu znanost, narativno znanje, znanstveni diskurz, modernu znanost i, na koncu, postmoderno društvo), odnosno legitimacija (koja se povezuje s autonomnom voljom, preskriptivnim i denotativnim iskazima, pričom) središnji su pojmovi poznate Lyotardove studije Postmoderno stanje. Izvještaj o znanosti (La Condition postmoderne: report sur le savoir, 1979.). U ovom prijevodu koristimo prijevod Tatjane Tadić (Lyotard, Jean-François. 2005. Postmoderno stanje. Izvještaj o znanosti. Zagreb: Ibis-grafika). Lyotard ističe da je znanstvena demoralizacija u postmoderni znatno utjecala na središnji problem legitimnosti te taj pojam za njega znači „proces kojim je 'zakonodavac' koji se bavi znanstvenim diskurzom ovlašten propisivati uvjete (općenito se radi o uvjetima unutrašnje konzistentnosti i eksperimentalne provjerljivosti) kako bi neki iskaz postao dijelom ovog diskurza, i kako bi ga znanstvena zajednica mogla uzeti u obzir" (ibid.: 10, op. prev.).

[3] Liotar, Ž.-F. 1994. Otvet na vopros: čto tako postmodern? (Prev. A. Garadži), „Ad Marginem '93. Ežegodnik." Moskva: Ad Marginem. Str. 79.

[4] 
Habermas, J. 2009. Moderna - nedovršeni projekt (prev. T. Martinović), „Politička misao”, sv. 46, br. 2, prosinac 2009. Str. 96-111. Tezu članka izgovorio je Habermas prilikom primanja Nagrade Theodora Adorna; prvo izdanje teksta: Habermas, J. 1981. Kleine politische Schriften I - IV. Frankfurt a. M. Str. 444-464.

[5] Tucker, R. 1985. Stalinism: Essays in Historical Interpretation. New York: Oxford University Press. Str. 90-99.

[6] Cohen, S. 1985. Rethinking Soviet Experience. New York: Oxford University Press.

[7] Lewin, M. 1985. The Making of Soviet System: Essays in the Social History of Interwar Russia. New York: Pantheon.

[8] Hoffman, D. L. 2003. Stalinist Values: The Cultural Norms of Soviet Modernity, 1917-1941. Ithaca: L.: Cornell University Press. Str. 7.

[9] Fitzpatrick, S. 1992. The Cultural Front: Power and Culture in Revolutionary Russia. Ithaca: Cornell University Press.

[10] Kotkin, S. 1995. Magnetic Mountain: Stalinism as Civilization. Berkeley: University of California Press. Str. 19-22, 72-155.

[11] Bauman, Z. 1992. Communism: A Postmortem. U: Beiharz, P. 2001. The Bauman Reader. Oxford: Bleckwell Publ. Str. 52-67.

[12] Osim knjige S. Kotkina, kao primjer korištenja te metodologije spomenut ćemo sljedeće knjige: Fitzpatrick, S. 1999. Everyday Stalinism: Ordinary Life in Extraordinary Times. Soviet Russia in the 1930's. New York. Oxford University Press; Fitzpatrick, S. (ur.) 2000. Stalinism: New Direction. London, New York: Routledge; Kivinen, M. 2005. Progress i haos: Sociologičeskij analiz prošlogo i buduščego Rossii (per. M. F. Černyševa). Sankt-Peterburg: Akademičeskij proekt; Halfin, I. (ur.) 
2002. Language and Revolution: Making Modern Political Identity. London, Portland: Frank Cass; Halfin, I. 2003. Terror in My Soul: Communist Autobiographies on Trial. Cambridge, MA; London: Harvard University Press; Kiaer, Ch.; Naiman, E, (ur.). 2006. Everyday Life in Early Soviet Russia: Taking the Revolution Inside. Bloomington and Inidianapolis: Indiana University Press; Hellbech, J. 2006. Revolution on My Mind: Writing a Diary Under Stalin. Cambridge, MA; London: Harvard University Press; Fitzpatrick, S. 2005. Tear Off the Mask! Identity and Imposture in TwentiethCentury Russia. Princeton: Princeton University Press; Dobrenko, E. 1997. Formovka sovetskogo čitatelja: Social'nye i èstetičeskie predposylki recepcii sovetskoj literatury. Sankt-Peterburg: Akademičeskij proekt; Dobrenko, E. 1999. Formovka sovetskogo pisatelja: Social'nye i èstetičeskie istoki sovetskoj literaturnoj kul'tury. Sankt-Peterburg: Akademičeskij proekt; Dobrenko, E. 2007. Politèkonomija socrealizma. Moskva: Novoe literaturnoe obozrenie; Kozlova, N. 2005. Sovetskie ljudi: Sceny iz istorii. Moskva: Evropa; V. također forum Analiz praktik sub"ektivizacii v rannestalinskom obščestve u časopisu „Ab Imperio” (2002., br. 3).

[13] Kotkin, S. 1995. Magnetic Mountain. Berkeley: University of California Press. Str. 293. V. također: Ryklin, M. 2002. Topos utopii. Kommunizm kak religija. U: Ryklin, M. Prostranstvo likovanija. Moskva: Logos. Str. 123-134.

[14] Gukov, L. 2002. Negativnaja identičenost': Stat'i 1997-2022 godov. Moskva: Novoe literaturnoe obozrenie. V. također: Gudkov, L. (ur.) 2005. Obraz vraga. Moskva: OGI.

[15] Višnevskij, A. G. 1998. Serp i rubl'. Konservativnaja modernizacija v SSSR. Moskva: OGI. Str. 30.

[16] Dobrenko, E. 2007. Politèkonomija socrealizma. Moskva: Novoe literaturnoe obozrenie. Str. $59,62-63$.

[17] Ryklin, M. 2002. Prostranstvo likovanija. Moskva: Logos. Str. 88-89.

[18] Battaile, G. 2011. Prokleti dio (prev. D. Bučan). Zagreb: Litteris; Girard, R. 1990. Nasilje i sveto (prev. S. Stanojević). Novi Sad: Biblioteka Novi anthropos.

[19] Kujundžić, D. 2003. Prizrak predstavlenija, ili Maska krasnoj smerti (prev. I. V. Borisova). U: Kujundžić, Dr. Vospalenie jazyka. Moskva: Ad Marginem.

[20] Ryklin, M. Ja. 2002. Prostranstvo likovanija. Moskva: Logos. Str. 47. 
[21] Halfin, I. 2003. Terror in My Soul. Communist Autobiographies on Trial Cambridge. MA; London: Harvard University Press. Str. 2.

[22] Ibid.: 283.

[23] Dobrenko, E. 2007. Politèkonomija socrealizma. Moskva: Novoe literaturnoe obozrenie. Str. 10. V. također važan tekst na tu temu: Ušakin, S. 2005. Pole boja na lone prirody: ot kakogo nasledstva my otkazivalis', „Novoe literaturnoe obozrenie”, br. 71. Str. 263-298.

[24] Dobrenko, E. 2007. Politèkonomija socrealizma. Moskva: Novoe literaturnoe obozrenie. Str. 45.

[25] V. o tome: Gudkov, L. 2006. Ideologema vraga. U: Gudkov, L. (ur.) Obraz vraga. Moskva: OGI. Str. 7-79.

[26] Mitrohin, N. 2003. Russkaja partija: Dviženie russkih nacionalistov v SSSR. 1953-1985. Moskva: NLO; Witte, G. 1983. Die sowjetische Kolchos- und Dorfprosa der fünfziger und sechziger Jahre. Zur Evolution einer literarischen Unterreihe. München; Dunlop, J. 1983. The Faces of Contemporary Russian Nationalism. Princeton: Princeton University Press; Parthé, K. 1992. Russian Village Prose: The Radiant Past. Princeton: Princeton University Press; Shrayer, M. 2000. Anti-Semitism and the Decline of Russian Village Prose, „Partisan Review”, ljeto, br. 67 (3). Str. 474-485.

[27] Vajl, P.; Genis, A. 2003. 60-e: Mir sovetskogo čeloveka. U: Vajl, P.; Genis, A. Sobranie sočinenij: V 2 tomah. Ekaterinburg: Y-Faktorija. Sv. 1. Str. 507-948; Savickij, S. 2002. Andergraund: Istorija i mify leningradskoj neoficial'noj literatury. Moskva: Novoe literaturnoe obozrenie; Bergman, J. 1992. Soviet Dissidents on the Russian Intelligentsia, 1956-1985: The Search for a Usable Past, „Russian Review”, siječanj, br. 51 (1). Str. 16-35; Woll, J.; Treml, V. 1983. Russian Dissident Literature: A Critical Guide. Boston: Hall; Shlapentokh, V. 2001. A Normal Totalitarian Society: How the Soviet Union Functioned and How It Collapsed. Armonk: M. E. Sharpe.

[28] V. o poetici A. D. Sinjavskog u: Nepomnyashchy, C. T. 1995. Abram Tertz and the Poetics of Crime. New Haven; London: Yale University Press. 
[29] O transformaciji službenoga diskurza tijekom 70-ih i 80-ih godina u: Yurchak, A.. 2006. Everything Was Forever Until It Was No More: The Last Soviet Generation. Princeton: Princeton University Press.

[30] Prigov, D. A.; Šapoval, S. 2003. Portretnaja galereja D. A. P. Moskva: Novoe literaturnoe obozrenie. Str. 93-95.

[31] Yurchak, A. 2006. Everything Was Forever Until It Was No More: The Last Soviet Generation. Princeton: Princeton University Press. Str. 1-35.

[32] Ruska riječ „steb” odnosi se na posebni žanr drske, ironične i sarkastične dosjetke (op. prev.).

[33] Sovjetska umjetnička skupina koja je djelovala u leningradskom undergroundu od 1962. do 1972. U svom su se umjetničkom izrazu oslanjali na poetiku obèriuta, Kručenyha, Hlebnikova, Vaginova te dadaiste (op. prev.).

[34] Savickij, S. 2002. Andergraund: Istorija i mify leningradskoj neoficial'noj literatury. Moskva: Novoe literaturnoe obozrenie. Str. 167-168.

[35] V. Kulakov, V. 1999. Poèzija kak fakt. Moskva: Novoe literaturnoe obozrenie. Str. 249-252.

[36] Skupina underground umjetnika koja je djelovala od kraja 50-ih do sredine 70 -ih godina prošloga stoljeća i koja je naziv dobila po mjestu Lianozovo, gdje su se sastajali. Oslanjali su se na iskustvo avangarde, pa ih se često naziva postavangardistima. Osim G. Sapgira, I. Holina, A. Satunovskog, Vs. Nekrasova i umjetnika i pjesnika E. Kropivnickog, krajem 60-ih godina u grupi je djelovao i È. Limonov (op. prev.).

[37] Skupina underground pisaca koja je djelovala od 1965. i čiji je naziv akronim od četiri temeljna načela skupine, odnosno Odvažnost (rus. Smelost'), Misao (rus. Mysl'), Karakter (rus. Obraz) i Dubina (rus. Glubina). Jedna od prvih skupina koja je javno otkazala poslušnost tadašnjoj sovjetskoj vlasti.

[38] McQuillan, M. 2000. Introduction: Five Strategies of Deconstruction. U: McQuillan, M. Deconstruction: A Reader. New York: Routledge. Str. 12-13.

[39] Derrida, Ž. 2004. Nasilije i metafizika. U: Levinas, Ė. Izbrannoe: Trudnaja svoboda. Per. A. V. Jampol'skoj. Moskva: Rosspèn. Str. 692. 
[40] Bahtin, M. M. 1997. Ritorika, v meru svoej lživosti. U: Bahtin, M. M. Sobranie sočinenij. T. 5. Moskva: Russkie slovari. Str. 65. Više o tom tekstu v. u: Lipoveckij, M.; Sandomirskaja, I. 2006. Kak ne „zaveršit" Bahtina? Perepiska iz dvuh èlektronnyh uglov. „Novoe literaturnoe obozrenie”, 79. Str. 7-38.

[41] Jedina je iznimka u tom smislu Varlam Šalamov, koji je tijekom 1960-ih godina pisao: „Svi su teroristi prošli stadij Tolstoja, tu vegeterijansku, moralizatorsku školu. Ruska književnost druge polovice 19. stoljeća (...) dobro je pripremila teren za krv koja je prolivena u 20. stoljeću pred našim očima” (Šalamov, V. 1989. Pis'mo k Ju. A. Šrejderu ot 24 marta 1968 goda, „Voprosy literatury”, br. 5, str. 232-233). Ili: „Krah njezinih (tj. klasične ruske književnosti, op. M. L.) humanističkih ideja, povijesni zločin koji je doveo do staljinskih logora i plinskih komora Auschwitza, dokazali su da su umjetnost i književnost - nula... To što se Izabrana djela Černyševskoga prodaju za pet kopjejki, spašavajući pretparačku književnost od Auschwitza, ima na višoj razini simboličko značenje. Černyševskij je umro nakon što se je stoljetna epoha do kraja diskreditirala.” („Novyj mir”, br. 12, 1989, str. 61). Detaljnije o tome vidi primjerice: Zolotonosov, M. 1994. Posledstvija Šalamova. U: Esipov, V. V. (ur.) Šalamovskij sbornik: Vyp. 1. Vologda: PF „Poligrafist”.

[42] V. o tome primjerice: Vattimo, G. 2008. Od utopije do heterotopije. U: Vattimo, G. Transparentno društvo (prev. N. Raspudić). Zagreb: Algoritam. Usp. „Upravo modernizam, a potom avangarda i postmodernizam dovode do novoga tipa umjetničkoga mitostvaralaštva orijentiranoga ne na nadvladavanje Kaosa Kozmosom nego na poetizaciju i razumijevanje Kaosa kao univerzalne i neodvojive forme ljudskoga postojanja. (...) U modernizmu se odnosi s Kaosom po prvi puta osvještavaju kao temelj umjetnosti i postavljaju kao njegov središnji sadržaj. Različite varijante stvaralačkih strategija, koje su proizašle iz takvog poimanja svijeta, oblikuju različite pravce modernističke i avangardističke umjetnosti. Zajedničko im je da se određuju radikalnim odustajanjem od pronalaska harmonije u 'objektivnoj' (povijesnoj, društvenoj, prirodnoj) stvarnosti." (Lejderman, N. L. 2002. Traektorii „èksperimentirujuščej” èpohi, „Voprosy literatury”, br. 4, str. 72).

[43] V. neke radove koji slijede takvu misaonu liniju: Najman, Ė. 1998. V žopu prorubit' okno: seksual'naja patologija kak ideologičeskij kalambur u Andreja Platonova (autorizorani prijevod E. Bernštejna), „Novoe literaturnoe obozrenie”, br. 32; Podoroga, V. Politika i filosofija. Novye vyzovy (doklad na Vtoroj Moskovskoj biennale sovremennogo iskusstva). 
http://2nd.moscowbiennale.ru/ru/podoroga_doklad1/ (o Šalamovu); Podoroga, V. 1999. GULAG v ume, „Indeks. Dos'e na cenzuru”, br. 7/8; Kalinin, I. 2005. Istorija kak iskusstvo členorazdel'nosti. (Istoričeskij opyt i metaliteraturnaja praktika russkih formalistov), „Novoe literaturnoe obozrenie”, br. 71; Livers, K. 2004. Turning Man Into Women: Andrei Platonov in the 1930's; Mikhail Zoshchenko: Engineering the Stalinist Body and Soul. U: Livers, K. Constructing the Stalinist Body. Lanham: Lexington Books.

[44] Po završetku knjige objavljena su nova djela spomenutih autora, konkretnije Empire $\mathrm{V}$ V. Pelevina i Den' opričnika V. Sorokina, film K. Serebrennikova prema drami V. i O. Presnjakovyh Izobražaja žertvu i roman Presnjakovyh pod istim nazivom, knjiga B. Akunina Nefritovye četki i ciklus njegovih romana Žanrovaja serija, filmovi A. Balabanova Mne ne bol'no i Gruz 200 te A. Rogožkina Peregon... O njima pišem ukratko - koliko mi je dopustila da im se posvetim kompozicija već dovršene knjige - te se nadam da ću se nekim temama vratiti u budućnosti.

\section{(c) (i) (9)}

Creative Commons Attribution-NonCommercial-NoDerivatives 4.0 International License 